\author{
S.V. Kim ${ }^{1}$, V.A. Kim 1 , O.R. Sariev², S.Kh. Kudarinov ${ }^{1}$, \\ O.A. Bogoyavlenskaya ${ }^{1}$, A.S. Orlov ${ }^{1}$, V.V. Orlova ${ }^{1}$, A.V. Zhdanov ${ }^{3}$ \\ ${ }^{I}$ Zh.N. Abishev Chemical-Metallurgical Institute, Karaganda, Kazakhstan; \\ ${ }^{2}$ K. Zhubanov Aktobe Regional State University, Kazakhstan; \\ ${ }^{3}$ Ural Federal University named after the first President of Russia B.N. Yeltsin, Yekaterinburg, Russia \\ (E-mail: o-bogoyavlenskay@mail.ru)
}

\title{
Influence of coal heat treatment parameters on physical-chemical properties of smokeless fuel
}

\begin{abstract}
A series of experiments on coking long-flame coals by high-speed thermooxidative pyrolysis was carried out as a part of smokeless fuel technology development from domestic energy coals. The objective of experiments was to determine the influence of basic technological parameters of the coking process (heating rate, coking temperature) on the final physical-chemical properties of the semi-coke, which is an initial material for briquetted smokeless fuel manufacture. The experiments were carried out in a Tamman resistance furnace at $600-1100{ }^{\circ} \mathrm{C}$ imitating the coking process in industrial shaft furnace. The rate of heating and the final temperature of coking were found the most important control factors ensuring the production of lump coke with sufficient strength. In the mentioned temperature interval, the reactivity of semi-coke changes by a complicated pattern varying from 3.5 to $9.7 \mathrm{ml} / \mathrm{g} \cdot \mathrm{s}$. Along with coking temperature and heating rate, the structural strength of semi-coke grows monotonically, reaching $80 \%$ at heating rate of 90 degrees per minute and a temperature of $1100{ }^{\circ} \mathrm{C}$. Thus, the results of this work allow us to conclude that the most rational temperature range for smokeless fuel production by means of high-speed pyrolysis of young high-volatile coal is found within $600-700{ }^{\circ} \mathrm{C}$ (the temperature interval of semi-coking). To ensure sufficient structural strength of semicoke the rate of coal heating should be at least $30^{\circ} \mathrm{C} / \mathrm{min}$. A highly active material with a reactivity of over $9 \mathrm{ml} / \mathrm{g} \cdot \mathrm{s}$ and a sufficiently high strength and a residual volatiles content of about $8-11 \%$ can be obtained using this method.
\end{abstract}

Keywords: smokeless fuel, thermo-oxidative pyrolysis, energy coals, semi-coke, coking temperature, structural strength, reactivity, volatile substances.

Long flame coal from the Shubarkol coal field was used as a raw material for smokeless fuel making. Shubarkol deposit with overall reserves of over 1.8 billion tons [1,2] is located in Tengiz area of Karaganda region. The coal is related to long flame (free-burning) coal type, is petrographically homogeneous and vitrinized. By reflectance, the coal is related to grade $\mathrm{D}$ (candle type) [3]. Coals are low-ash, low-sulfur with low phosphorus content, easy and medium-enriching. The content of vitrinite is over $80 \%$ of the organic mass. The reflection is $0.6 \%$. The quality of coals according to exploration data is as follows: $\mathrm{W}^{\mathrm{p}}-15 \%$; $\mathrm{A}^{\mathrm{d}}-5 \div 15 \% ; \mathrm{V}^{\mathrm{daf}}-40 \% ; \mathrm{S}_{\mathrm{t}}^{\mathrm{d}}-0.5 \% ; \mathrm{C}^{\mathrm{daf}}-76 \% ; \mathrm{H}^{\mathrm{daf}}-5.5 \% ; \mathrm{Q}_{\mathrm{s}}{ }^{\mathrm{daf}}-26 \mathrm{MJ} / \mathrm{kg} ; \mathrm{Q}_{\mathrm{i}}^{\mathrm{r}}-22 \mathrm{MJ} / \mathrm{kg}$. It can be seen that for Shubarkol coal has distinctively low ash content. In separate parts of the coal bed, the ash level has extreme values of 1.4 and $31.0 \%$. At the same time, the bulk of coal contains $6.0 \%$ ash and below.

The method of high-speed thermooxidizing coking was used to obtain durable lump material from sieved Shubarkol coal based on the rapid heating of coal particles by heat released during the combustion of volatile products of thermal destruction [4-6]. In this process, the formation of the coke structure goes through a series of reactions of coal matter decomposition and the synthesis of new compounds with the formation of semi-coke. Further transformations of the latter lead to the formation of a carburized coke material [7].

To simulate coal heating conditions of high-speed thermooxidizing coking, we used the Tamman resistance furnace, into which a crucible of heat-resistant steel with a coal sample inside was introduced. The crucible has high walls to provide access of air oxygen into the reaction zone. The electric supply of the heater is provided by a power transformer of $80 \mathrm{kVA}$ with thyristor regulation of voltage and current, which allows maintaining the set temperature with an accuracy of $10^{\circ} \mathrm{C}$. A portion of the coal charge was prepared from the 10-20 mm Shubarkol coal. The temperature in the furnace and in the coal layer was constantly measured during the experiment. After the experiment, the residue was weighted to determine the mass loss.

The studies were carried out at a strictly fixed temperature, which was varied from 600 to $1100{ }^{\circ} \mathrm{C}$ with the interval of $100^{\circ} \mathrm{C}$. A sample of coal in a heat-resistant steel reactor was loaded into a preheated furnace. During the experiment, a continuous measurement of the temperature in the coal bed was made and, after 
reaching a predetermined level of heating, an exposure was held for 5 minutes. After that, the reactor was removed from the furnace and cooled in a sealed container to room temperature. The coking gas evolved in the process of pyrolysis was burned down outside the furnace.

In order to eliminate the influence of heat loss by moisture evaporation, the beginning of recording the temperature in the layer is attributed to the dry state of the material. The zero test time corresponds to coal sample temperature of $180-250^{\circ} \mathrm{C}$, at which point the physical moisture is completely removed from the sample (Fig. 1).

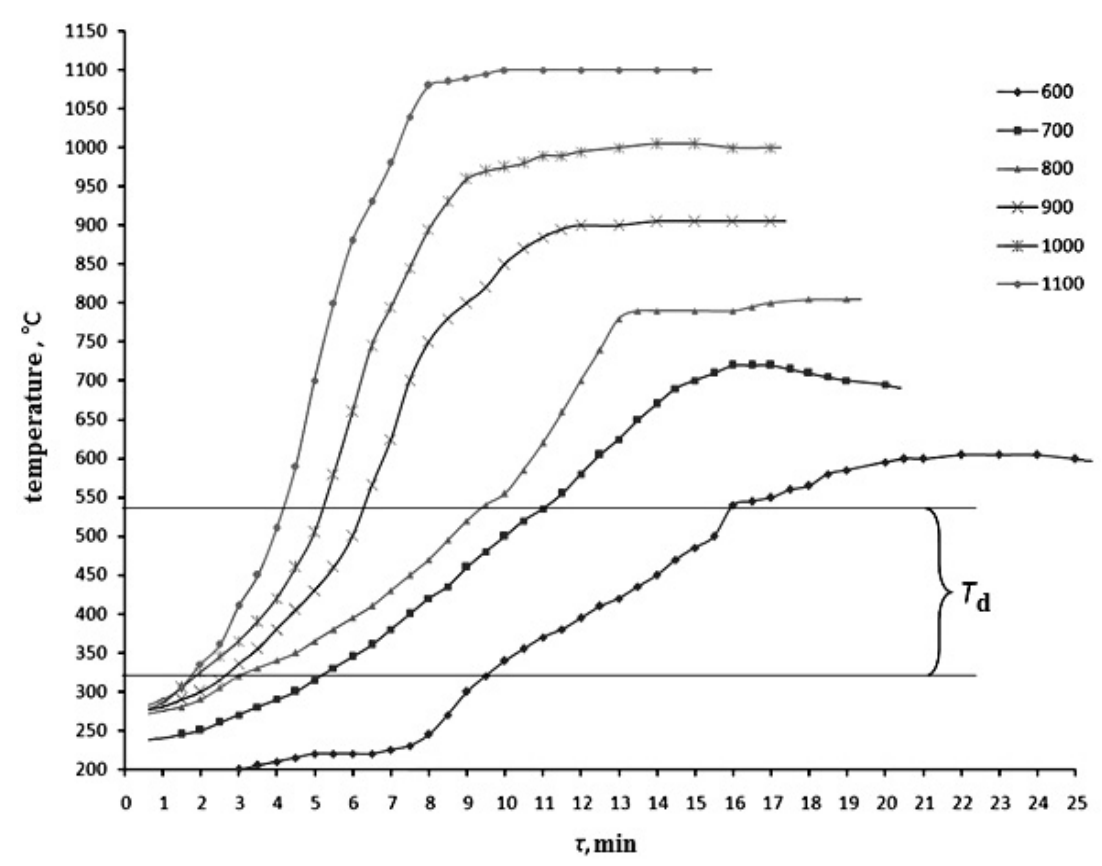

Figure 1. Dynamics of temperature changes in the coal layer at various initial temperatures in the furnace

The influence of temperature and coal heating rate on the structure and properties of the coking product was studied experimentally. The process of high-speed pyrolysis of coal was imitated by pre-heating the furnace to certain degree, which allowed heating the coal samples with varying temperature gradients [8]. The dynamics of the temperature change in the coal layer is shown in Figure 1 as a function of time and the initial temperature level in the furnace.

The data in Figure 1 show that in the temperature range of $320-540{ }^{\circ} \mathrm{C}$ corresponding to coal matter destruction processes the rate of coal heating depends on the preset temperature gradient and amounts to 29.4 90.9 degrees per min (Fig. 2), which is sufficient for the formation of a stable structure of the coke residue (semi-coke).

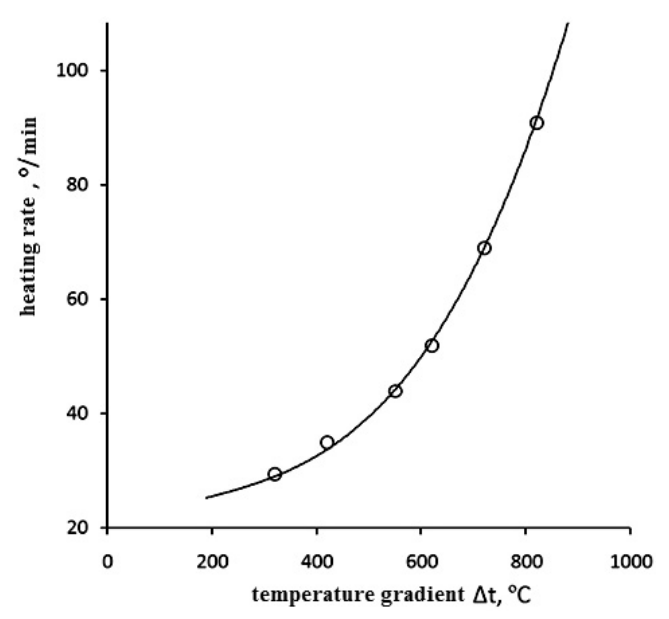

Figure 2. Effect of the temperature gradient on the coal heating rate 
Table represents the data on the heating rate and the numerical values of coal mass loss and the results of the proximate analysis of semi-coke samples obtained in interval of $600-1100{ }^{\circ} \mathrm{C}$ and heating rates of 29.4-90.9 degrees per minute.

$\mathrm{T}$ a b l e

Parameters of high-speed coking process and proximate composition of semi-coke

\begin{tabular}{|c|c|c|c|c|c|}
\hline \multirow{2}{*}{ Temperature, ${ }^{\circ} \mathrm{C}$} & \multirow{2}{*}{ Heating rate, $\%$ min } & \multirow{2}{*}{ Mass loss, $\%$} & \multicolumn{3}{|c|}{ Proximate composition of the product, \% } \\
\cline { 3 - 6 } & & $\mathrm{A}^{\mathrm{c}}$ & \multicolumn{1}{|c|}{$\mathrm{V}^{\mathrm{d}}$} & $\mathrm{W}^{\mathrm{r}}$ \\
\hline 600 & 29.41 & 42.5 & 3.01 & 11.02 & 2.76 \\
\hline 700 & 35.7 & 47.0 & 3.23 & 3.74 & 3.54 \\
\hline 800 & 45.45 & 47.8 & 3.48 & 3.04 & 4.17 \\
\hline 900 & 53.57 & 50.3 & 3.61 & 2.86 & 3.31 \\
\hline 1000 & 65.22 & 51.0 & 3.80 & 0.45 & 3.37 \\
\hline 1100 & 90.90 & 49.8 & 3.95 & & \\
\hline
\end{tabular}

As we can see, the residual amount of volatiles in the semi-coke (see Table) is in full compliance with coal mass loss (Fig. 3). It can be seen that the most intensive loss of coal mass is observed at low temperatures of $600-800^{\circ} \mathrm{C}$ where the greatest decrease of volatiles level takes place. The level of volatile substances stabilizes after $800{ }^{\circ} \mathrm{C}$ and varies insignificantly from 3.22 to $2.86 \%$ up to $1000{ }^{\circ} \mathrm{C}$. It is only above $1100{ }^{\circ} \mathrm{C}$, that the volatiles level sharply decreases, reaching $0.45 \%$. At a temperature of $950-1000{ }^{\circ} \mathrm{C}$ the structure of the semi-coke begins to decompose with the release of heavy resins containing hydrogen.

Evaluation of structural strength and reactivity of semi-coke samples obtained at different heating rate and temperature was carried out in accordance with State Standards, namely, «State Standard 9521-74» and «State Standard 10089-89». Evaluation results are shown in the Figure 4. The structural strength of the semicoke is minimal (no more than $50 \%$ ) in the low temperature range of $600-700{ }^{\circ} \mathrm{C}$ and at a heating rate below 40 degrees per min. The most noticeable increase in the structural strength occurs in the interval of 700 $800{ }^{\circ} \mathrm{C}$ and the heating rate range of $40-60$ degrees per minute, where structural strength reaches $72 \%$.

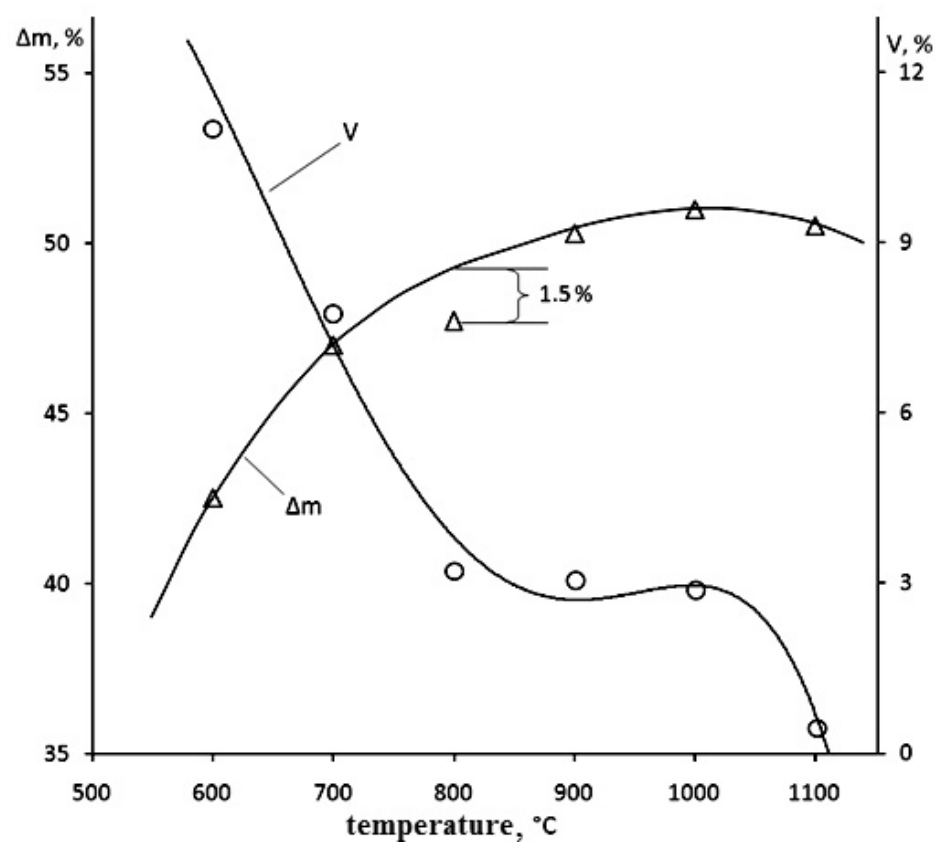

Figure 3. Dependence of mass loss $(\Delta m)$ and residual volatiles level $(V)$ from the coking temperature

The monotonous growth of the structural strength up to $80 \%$ is observed at a heating rate of $90^{\circ}$ degrees per minute and a temperature of $1100{ }^{\circ} \mathrm{C}$. The rate of heating and the final temperature of coking are, therefore, the most important control factors ensuring the production of lump coke with sufficient strength, as follows from the experimental data. 


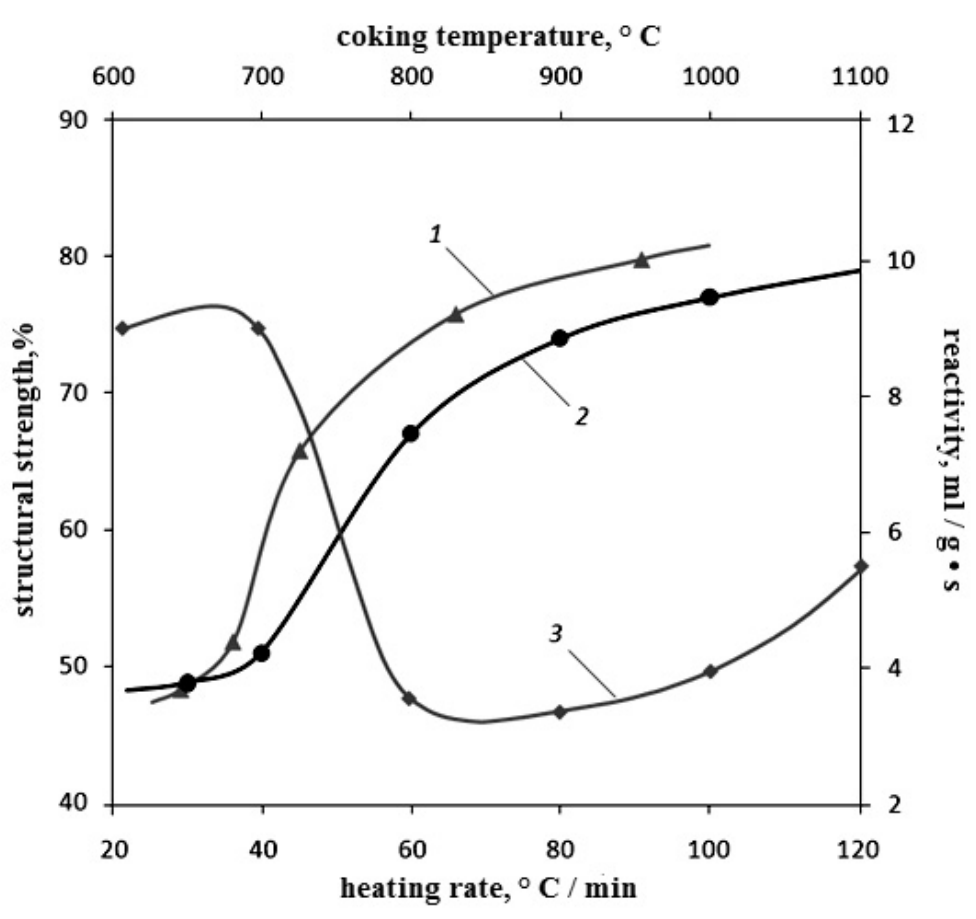

Figure 4. Influence of heating rate (1) and temperature (2) on structural strength and temperature (3) on the reactivity of semi-coke

It follows from the data in Figure 4 that the level of reactivity of semi-coke varies within $3.5-9.7 \mathrm{ml} / \mathrm{g} \cdot \mathrm{s}$ in the investigated temperature range, and, while the coking temperature grows monotonically, the reactivity variation follows more complicated pattern. Semi-coke has greatest reactivity, which reaches $9.7 \mathrm{ml} / \mathrm{g} \cdot \mathrm{s}$, at $600-700{ }^{\circ} \mathrm{C}$. Growth of coking temperature from 600 to $700{ }^{\circ} \mathrm{C}$ has very slight influence on overall reactivity. However, the latter sharply decreases to $3.5 \mathrm{ml} / \mathrm{g} \cdot \mathrm{s}$ in the interval of $700-800{ }^{\circ} \mathrm{C}$ and remains practically unchanged up to $900{ }^{\circ} \mathrm{C}$, after which point it begins to increase faster to reach $5.6 \mathrm{ml} / \mathrm{g} \cdot \mathrm{s}$ at $1100{ }^{\circ} \mathrm{C}$.

\section{Conclusion}

Thus, the results of this work allow us to conclude that the most rational temperature range for smokeless fuel production by means of high-speed pyrolysis of young high-volatile coal is found within 600 $700{ }^{\circ} \mathrm{C}$ (the temperature interval of semi-coking). The production of the most reactive material, with a sufficiently high strength and a residual volatile content of about $8-11 \%$, is ensured under these conditions. This semi-coke considering its basic physical-chemical and technological properties can be proposed as a highquality intermediate material for further production of smokeless fuel.

The work was performed within the program-purpose financing O. 0787 Project for 2018-2020. «Development of smokeless fuel production technology and creation of an experimental coal coking plant».

\section{References}

1 Ким В.А. Промышленные испытания технологии термоокислительного коксования угля Шубаркольского разреза/ В.А. Ким, М.Ж. Ахмеров, А.К. Надырбеков // Промышленность Казахстана. - 2001. — № 2. - С. 101-103.

2 Ким В.А. Получение спецкокса из шубаркольских углей / В.А. Ким, А.М. Ли, А.К. Надырбеков // Комплексная переработка минерального сырья: материалы совещ. - Алматы, 2002. - С. 411-415.

3 Глезин И.Л. Полукоксование длиннопламенных углей Шубаркольского месторождения в газогенераторах / И.Л. Глезин, В.М. Шампаров, В.М. Страхов, И.В. Суровцева // Кокс и химия. — 2009. — № 8. - С. $25-29$.

4 Matuszek K. Carbonaceous smokeless fuel and modern small-scale boilers limiting the residential emission. Part 2. Experimental tests of a new carbonaceous smokeless fuel / K. Matuszek, P. Hrycko, S. Stelmach, A. Sobolewski // Przemysl Chemiczny. 2016. - Vol. 95, No. 2. - P. 228-230.

5 Bai Y. Gasification of coal char in $\mathrm{H}_{2} \mathrm{O} / \mathrm{CO}_{2}$ atmospheres: Evolution of surface morphology and pore structure / Y. Bai, P. Lv, X. Yang // Fuel. — 2018. - Vol. 218. - P. 236-246.

6 Wang H.P. Thermal decomposition mechanisms of coal and coal chars under $\mathrm{CO}_{2}$ atmosphere using a distributed activation energy model / H.P. Wang, Z.C. Chen, X.Y. Zhang // Thermochimica Acta. - 2018. — Vol. 662. — P. 41-46. 
7 Сысков К.И. Термоокислительное коксование углей: монография / К.И. Сысков, О.Н. Машенков. - М.: Металлургия, 1973. - $176 \mathrm{c}$.

8 Мирошниченко Д.В. Влияние технологических факторов подготовки и коксования углей на реакционную способность кокса / Д.В. Мирошниченко // Кокс и химия. — 2009. — № 2. - С. 37-42.

\author{
С.В. Ким, В.А. Ким, О.Р. Сариев, С.Х. Кударинов, \\ О.А. Богоявленская, А.С. Орлов, В.В. Орлова, А.В. Жданов
Көмірді термиялық өндеу режимдерінің түтінсіз отынның физика-химиялық қасиеттеріне әсерін зерттеу

\begin{abstract}
Отандық энергетикалық көмірлерден түтінсіз отынды өндіру технологиялын жасау шарасында жоғары жылдамдықты термототықтырғыш пиролиз тәсілімен ұзын жалынды көмірлерді кокстау бойынша зерттеу жұмыстары жүргізілді. Кокстау процесінің негізгі технологиялық параметрлерінің (қыздыру жылдамдығы, кокстау температурасы) жартылай кокстың — брекеттелген түтінсіз отынды алуға арналған бастапқы материалдың сонғы физика-химиялық қасиеттеріне әсері орнатылды. Зерттеу өндірістік шахталы пештердегі көмірді кокстау процестерін келтіретін, $600-1100{ }^{\circ} \mathrm{C}$ температурада Таммана кедергілі пешінде жүргізілді. Зерттеу мәліметтерінің талдауы кокстаудың қыздыру жылдамдығы және соңғы жылдамдығы кесекті және берік жартылай коксты алуына ықпал ететін анықтағыш негізгі фактор болып есептеледі. Зерттелген температура аралығында жартылай кокстың реакциялық қабілеті күрделі заңдылық бойынша өзгереді және 3,5-9,7 мл/г`с шамасы аралығында ауытқиды. Қыздыру жылдамдығын және температурасын жоғарылату барысында қыздыру температурасы 90 град/мин және температурасы $1100{ }^{\circ} \mathrm{C}$ кезінде $80 \%$ жететін жартылай кокстың монотонды құрылымдылық өсуі байқалады. Зерттеу шешімі бойынша бастапқы ұшқыш заттардың жоғары мөлшеріне ие жас көмірлерден жоғары жылдамдықты пиролиз тәсілімен алынатын түтінсіз отынды термиялық өңдеу температурасы $600-700{ }^{\circ} \mathrm{C}$ (жартылай кокстау және жартылай коксты алу температурасы интервалы) неғұрлым ұтымды болып келеді. Жартылай кокстың жеткілікті құрылымдық беріктігін қамтамасыз ету үшін көмірді қыздыру жылдамдығы $30^{\circ} \mathrm{C} /$ мин кем болмауы керек. Бұнын өзінде жоғары белсенді материал, реакциялық қабілеті 9 мл/гc кем емес, жеткілікті беріктікке ие және қалдық ұшқыш заттар мөлшері 8-11 \% болатын алу қамтамасыз етіледі.
\end{abstract}

Кілт сөздер: түтінсіз отын, термототықтырғыш пиролиз, энергетикалық көмір, жартылай кокс, кокстау температурасы, құрылымдық беріктік, реакцияға қабілеттілік, ұшқыш заттар шығыны.

\author{
С.В. Ким, В.А. Ким, О.Р. Сариев, С.Х. Кударинов, \\ О.А. Богоявленская, А.С. Орлов, В.В. Орлова, А.В. Жданов \\ Влияние режимов термообработки угля
на физико-химические свойства бездымного топлива
}

В рамках создания технологии производства бездымного топлива из отечественных энергетических углей проведена серия экспериментов по коксованию длиннопламенных углей методом высокоскоростного термоокислительного пиролиза. Установлено влияние основных технологических параметров процесса коксования (скорости нагрева, температуры коксования) на конечные физико-химические свойства полукокса - исходного материала для получения брикетированного бездымного топлива. Опыты проводили в печи сопротивления Таммана при температуре $600-1100{ }^{\circ} \mathrm{C}$ в условиях, имитирующих процесс коксования угля в промышленной шахтной печи. Анализ экспериментальных данных указывает на то, что скорость нагрева и конечная температура коксования являются определяющими, наиболее важными факторами, влияющими на получение кускового и прочного полукокса. В исследованном диапазоне температур величина реакционной способности полукокса изменяется по сложной закономерности и колеблется в пределах 3,5-9,7 мл/г·с. При повышении температуры и скорости нагрева наблюдается монотонный рост структурной прочности полукокса, достигающей $80 \%$ при скорости нагрева 90 град/мин и температуре $1100^{\circ} \mathrm{C}$. По результатам исследований определено, что для бездымного топлива, получаемого методом высокоскоростного пиролиза из молодых углей с высоким исходным содержанием летучих веществ, температура термообработки $600-700{ }^{\circ} \mathrm{C}$ (температурный интервал полукоксования и получения полукокса) является наиболее рациональной. Для обеспечения достаточной структурной прочности полукокса скорость нагрева угля должна быть не менее $30{ }^{\circ} \mathrm{C} /$ мин. При этом обеспечивается получение высокоактивного материала с реакционной способностью не менее 9 мл/г·c, с достаточно высокой прочностью и содержанием остаточных летучих веществ около 8-11\%.

Ключевые слова: бездымное топливо, термоокислительный пиролиз, энергетические угли, полукокс, температура коксования, структурная прочность, реакционная способность, выход летучих веществ. 


\section{References}

1 Kim, V.A., Akhmerov, M.Zh., \& Nadyrbekov, A.K. (2001). Promyshlennye ispytaniia tekhnolohii termookislitelnoho koksovaniia uhlia Shubarkolskoho razreza [Industrial tests of technology of thermo-oxidative coking of coal of Shubarkolsky mine]. Promyshlennost Kazakhstana - Industry of Kazakhstan, 2, 101-103 [in Russian].

2 Kim, V.A., Li, A.M., \& Nadyrbekov, A.K. (2002). Poluchenie spetskoksa iz shubarkolskikh uhlei [Obtaining a special coke from Shubarkol coals]. Kompleksnaia pererabotka mineralnoho syria [Complex processing of mineral raw materials]. Almaty [in Russian].

3 Glezin, I.L., Shamparov, V.M., Strakhov, V.M., \& Surovtseva, I.V. (2009). Polukoksovanie dlinnoplamennykh uhlei Shubarkolskoho mestorozhdeniia $\mathrm{v}$ hazoheneratorakh [Semicoking of long-flame coals of the Shubarkol field in gas generators]. Koks i khimiia. - Coke and chemistry, 8, 25-29 [in Russian].

4 Matuszek, K., Hrycko, P., Stelmach, S., \& Sobolewski, A. (2016). Carbonaceous smokeless fuel and modern small-scale boilers limiting the residential emission. Part 2. Experimental tests of a new carbonaceous smokeless fuel. Przemysl Chemiczny, 95, 2, 228-230.

5 Bai, Y., Lv, P., \& Yang, X. (2018). Gasification of coal char in $\mathrm{H}_{2} \mathrm{O} / \mathrm{CO}_{2}$ atmospheres: Evolution of surface morphology and pore structure. Fuel, 218, 236-246.

6 Wang, H.P., Chen, Z.C., \& Zhang, X.Y. (2018). Thermal decomposition mechanisms of coal and coal chars under $\mathrm{CO}_{2}$ atmosphere using a distributed activation energy model. Thermochimica Acta, 662, 41-46.

7 Syskov, K.I., \& Mashenkov, O.N. (1973). Termookislitelnoe koksovanie uhlei [Thermo-oxidative coking of coals]. Moscow: Metallurhiia [in Russian].

8 Miroshnichenko, D.V. (2009). Vliianie tekhnolohicheskikh faktorov podhotovki i koksovaniia uhlei na reaktsionnuiu sposobnost koksa [The influence of technological factors in the preparation and coking of coals on the reactivity of coke]. Koks $i$ khimiia - Coke and chemistry, 2, 37-42 [in Russian]. 